\title{
The political ecology of wildlife conservation and trophy hunting in human-dominated landscapes of southern Africa: a review
}

\author{
Never Muboko ${ }^{1}$ \\ Chinhoyi University of Technology, Zimbabwe
}

\begin{abstract}
Drawing from a historical conservation perspective and political ecology, this review mediates the growing debate on wildlife conservation and hunting, especially in human-dominated landscapes of Africa. The focus is to 1) trace how socio-political changes during and after colonization transformed the hunting and wildlife conservation discourse in southern Africa, and 2) to address how previous conservation injustices were addressed through benefit-based approaches like CAMPFIRE, adopted in Zimbabwe after colonization. Some 144 published journal articles, books and other source materials were consulted. The review indicates that political changes in southern Africa profoundly transformed the conservation and trophy hunting narrative. This narrative had varied impacts and outcomes for different groups of people. Although a number of benefit-based approaches, like CAMPFIRE reflected a complete departure from past conservation policies, they continue to attract praise and criticisms since opinions differ among stakeholders, especially over extractive activities like trophy hunting and its associated benefits. I conclude that political developments impacted on conservation and trophy hunting in a profound way and that although post-colonial, procommunity conservation programs have inherent weaknesses, to a greater extent they addressed past conservation-based injustices. Continuous monitoring and area-specific adaptive management of wildlife and its sustainable management is recommended for long-term conservation benefits and community livelihoods.
\end{abstract}

Key words: Livelihoods, local community, trophy hunting, trade, participation, wildlife

\section{Résumé}

Cet examen de l'écologie politique de la conservation de la faune et de la chasse dans les paysages dominés par l'homme en Afrique adopte une perspective de conservation historique. L'objectif est 1) de retracer comment les changements sociopolitiques pendant et après la colonisation ont transformé le discours sur la chasse et la conservation de la faune en Afrique australe, et 2) de traiter de la manière dont les injustices antérieures en matière de conservation ont été traitées grâce à des approches fondées sur les avantages comme CAMPFIRE, adoptée au Zimbabwe après la colonisation. Quelque 144 articles de revues, livres et autres sources ont été consultés. L'étude indique que les changements politiques en Afrique australe ont profondément transformé le récit de la conservation et de la chasse aux trophées. Ce récit a eu des impacts et des résultats variés pour différents groupes de personnes. Bien qu'un certain nombre d'approches présentant des avantages pour les populations locales comme CAMPFIRE s'écartent complètement des politiques de conservation antérieures, elles continuent d'attirer des critiques et les opinions divergent parmi les parties prenantes (en particulier sur la chasse aux trophées). Je conclus que les développements politiques ont profondément affecté la conservation et la chasse aux trophées. Bien que les programmes de conservation postcoloniaux et pro-communautaires présentent des faiblesses intrinsèques, ils ont dans une plus large mesure abordé les injustices du passé fondées sur la conservation. Une surveillance continue et une gestion adaptative spécifique à la zone de la faune sont recommandées pour les avantages de la conservation à long terme et les moyens de subsistance des communautés.

Mots clés: moyens de subsistance, communauté locale, chasse aux trophées, commerce, participation, faune

\footnotetext{
${ }^{1}$ Prof. Never Muboko, Department of Wildlife Ecology and Conservation, Chinhoyi University of Technology, Private Bag 7724, Chinhoyi, Zimbabwe. Email: nmbok "at" yahoo.co.uk. The author would like to thank Chinhoyi University of Technology, Zimbabwe, for providing access to internet and library facilities that made this study possible and the anonymous reviewers whose contributions added value to the quality of the article. The author has no conflict of interests to disclose.
} 


\section{Resumen}

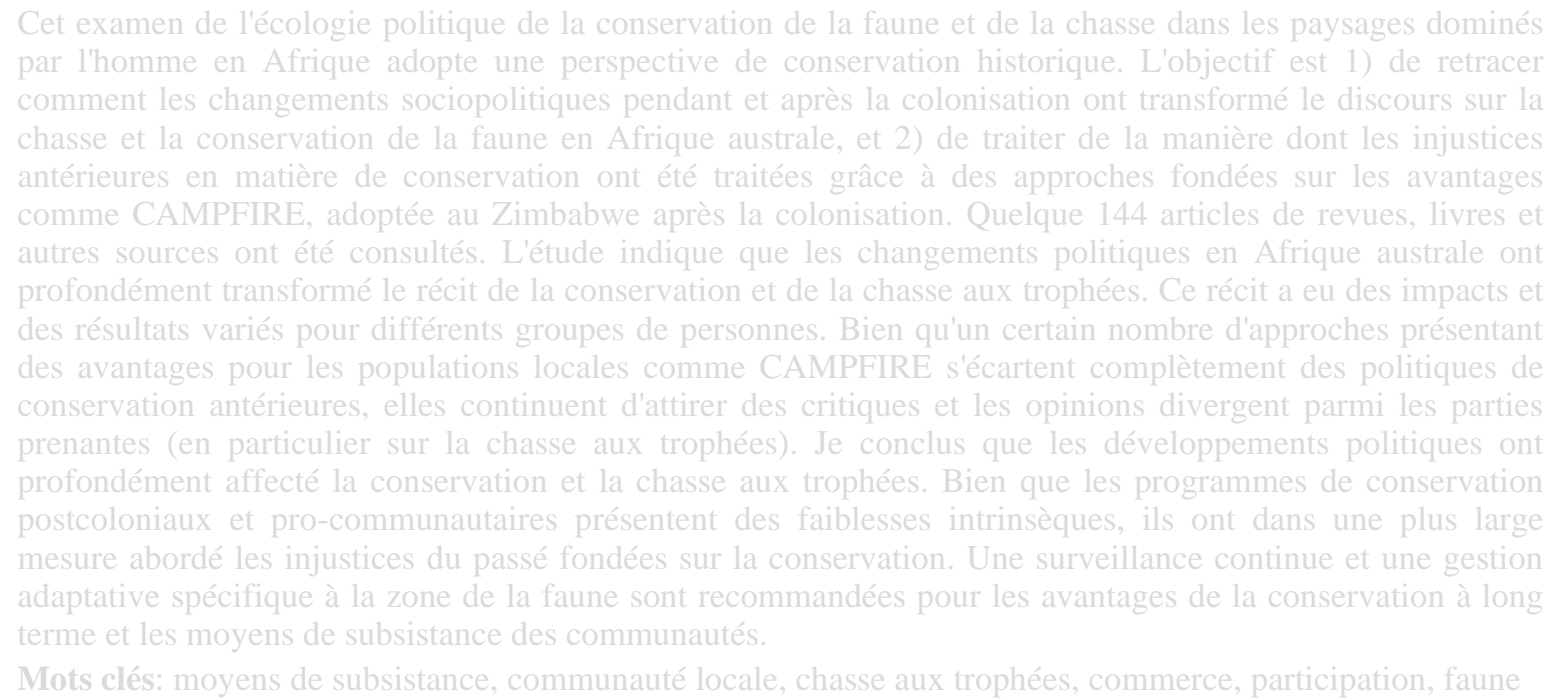

\section{Introduction}

Hunting is a livelihood strategy dating back to the dawn of humanity in Africa, with complex spatial and temporal patterns of evolution and change (Fitzwater 1970; Lindsey et al. 2007). Many definitions of hunting exist. For example Bird et al. (2005) define it as time spent searching, tracking, and capturing game, while Robinson and Bennett (2000) include within it, capture, by humans of wild mammals, birds, and reptiles, whether dead or alive, irrespective of the techniques used. The term conservation has different meanings to different actors depending on context (Miller et al. 2004). To an interventionist, conservation is the wise use of a country's resources, especially of land, water and wildlife (Usher 1986), while Holt and Talbot (1978) acknowledge a variety of meanings but signal "...keeping for future use." The reference to wise use in defining conservation is cross-cutting, and supports Aldo Leopold, an early American conservationist, who advanced similar concepts and ideas in his book, Game management (1987[1933]).

In Africa, the history of trophy hunting and conservation has involved controversial legal and institutional frameworks, inequitable economic development opportunities, and an unequal politics of race and of access to resources. Focusing on Southern Africa, this review attempts to address the following objectives; 1) to trace how socio-political changes during and after colonization transformed the hunting and wildlife conservation landscape in the region and, 2) to understand post-colonial legislative reforms and how the associated benefit-based approaches addressed past conservation injustices in southern Africa, taking CAMPFIRE in Zimbabwe as a case.

\section{Literature review process}

A literature search method was adopted to revisit factors surrounding debates about trophy hunting and wildlife conservation. This review is informed by political ecology, which focuses on political, economic and social structures and processes underpinning human practices that lead to environmental problems. Early work noted these concerns were missing in most debates over environmental degradation and the decline of wild animal populations in Africa (Anderson and Grove 1987; Neumann 2002). Political ecology places importance on historical analysis in understanding the development of social relationships and their influence on environmental issues (Blaikie and Brookfield 1987; Neumann 1992). In the context of this study the political ecology perspective is used to support an analysis of the association between historical developments in the form of politics, power and economic events, and the viewpoints taken over wildlife conservation and trophy hunting. 
Internet sources, published cases and grey literature, books and official reports were first examined between April 2018 and May 2019. Although the review focused mainly on southern Africa, some worldwide literature covers the period 1909-2019. The review process followed methods used by Brockington and Igoe (2006). Google Scholar and Science Direct were searched, with the following terms: 'hunting and colonialism', 'trophy hunting legislation and southern Africa', 'colonialism and wildlife conservation', 'political ecology and trophy hunting', 'post-colonial and conservation strategies', 'trophy hunting debates', 'local community and benefits and wildlife conservation attitudes' and 'trophy hunting and trade restrictions'. Citations were tracked, and only peer-reviewed publications written in English were included in the final selection of articles.

The final document selection and analyses were done through the use of the preview, question, read and summarize (PQRS) system (Cohen 1990). For document selection and later downloading, the title, abstract or summary and conclusions were gleaned for the presence of any two or more of the key search words or phrases, and if present, the document was preselected and later downloaded for further examination by PQRS. This resulted in 144 source materials being finally selected and qualitatively analyzed out of 225 documents identified through databases and other sources. The PQRS system allows for the use of an inductive qualitative data analysis approach, where themes were derived from interpreting each downloaded article and later grouping issues into each of the identified themes following Thomas (2006), Westwood (2001) and Muboko (2017). These themes allowed an analysis of the history, costs, benefits and controversies associated with trophy hunting and wildlife conservation in each article. This analytical framework provided an opportunity to collate and understand key issues from varied sources and perspectives.

\section{Trophy hunting and benefit-based approaches}

Contests over trophy hunting as a tool for wildlife conservation among scientists, wildlife conservationists, practitioners, and other stakeholders have historical roots (Akama 2007; Buckley and Mossaz 2015; Brandon et al. 1998; Dickson et al. 2009; Festa-Bianchet 2017; Gunn 2001; Leader-Williams and Hutton 2005). Contestation was initially driven by ecological concerns but has become more political over time, increasingly pitting developed versus developing countries. In the case of Zimbabwe, a developing country, the controversies heightened in the midst of geo-political tensions, when the US Congress imposed the Zimbabwe Democracy and Economic Recovery Act of 2001. It was designed to restrict trade in all economic sectors including wildlife. Tensions were reinforced with the imposition of restrictive measures by the US Fish and Wildlife Service (USFWS) when it suspended elephant trophy hunting and ivory imports from Tanzania and Zimbabwe into the United States. ${ }^{2}$ The reasons for the suspension included 'questionable management practices', 'lack of effective law enforcement' and 'weak governance.' These allegations were refuted by the two targeted countries. Later incidents included the legal hunting of a black rhino (Diceros bicornis) in Namibia in 2015 to generate revenue for endangered species conservation, and the widely publicized hunting of Cecil the Lion in Zimbabwe in 2015 under controversial circumstances (Di Minin et al. 2016; Godoy 2020). These incidences, among others, gave ammunition to the movements advocating for banning trophy hunting. The trophy hunting ban was, however, viewed as politically motivated, particularly for countries whose policies were regarded as a threat to American foreign interests. In Southern Africa, the USA is one of the major trophy hunting and ivory consumer countries (Martin and Stiles 2008), and due to its global economic and market share, the effects of its foreign policy and the decisions it makes are significant for the conservation and hunting industry throughout the world.

In addition, the debates over trophy hunting take place in varied socio-economic, geo-political, historical and environmental contexts. For instance, a significant proportion of large-sized wild animals exist outside designated protected areas (PAs) (Riddle et al. 2010; Kamal et al. 2015; Western et al. 2015), and need similar protection to those inside them (Child 1995; Taylor 1993). The protection of wild animals outside designated PAs and particularly those in human-dominated landscapes present a number of

\footnotetext{
${ }^{2}$ USFWS press release dated 4 April 2014 (restrictions were later loosened on 1 March 2018).
} 
conservation and socio-economic challenges which are well documented (Nygren 2004; Leader-Williams and Hutton 2005; Sayer et al. 2013).

In order to ameliorate such challenges and promote co-existence between humans and wild animals, strategic interventions such as benefit-based approaches grounded in concepts like the 'sustainable use' of wild animals have been adopted. This adoption has been reflected through programs like community-based natural resources management (CBNRM) or integrated conservation and development projects (ICDP) (Leader-Williams et al. 1990; Alpert 1996; Kideghesho 2006; Sayer et al. 2017). Some of these benefit-based approaches are anchored to extractive uses including trophy hunting (Lindsey et al. 2007). They are broadened to include revenue sharing mechanisms with local communities living adjacent to areas where trophy hunting activities take place.

Hunting, including trophy hunting, is a tradition which contributes significantly to conservation and national economies (Aiyadurai 2011). For example, in the USA trophy hunting contributes to conservation via taxation (Loveridge, Reynolds et al. 2007). In Australia, before the advent of the Covid-19 pandemic in 2019, deer hunters spent over AU\$100 million (US\$79.9 million) annually (Sharp and Wollscheid 2009). In sub-Saharan Africa, 23 countries have legalized trophy hunting and practice it as both an economic and conservation tool (Baker 1997; Lindsey et al. 2007) and prior to the Covid-19 pandemic in 2019, trophy hunting generated at least US\$201 million annually from approximately 18,500 international hunting clients (Lindsey 2008). South Africa, which attracts the majority of inbound hunters on the African continent, takes the bulk, e.g. over 7,000 foreign hunters injected about US\$130 million to the economy in the 2003/4 fiscal year, while an estimated 200,000 resident hunters spent about US\$452 million within the same period (Damm 2005; PHASA 2006). Again, in South Africa, in 2012 US\$68 million and over US\$130 million in 2016 was generated from trophy hunting (Di Minin et al. 2016; Van der Merwe 2018).

Benefit-based approaches are also supported by various national, regional and international legislative frameworks, principles and conventions. For example, at the African continental level, instruments such as the Addis Ababa Principles and Guidelines for the Sustainable Use of Biodiversity (CBD Guidelines) promote the sustainable use of biodiversity resources (Principles 2004). At the international level, multilateral environmental agreements (MEAs) or conventions exist, for example, the Convention on Biological Diversity (CBD) and its AICHI targets, especially target 4. Also, the IUCN Policy Statement on Sustainable Use of Wild Living Resources states that the "use of living resources, if sustainable, is an important conservation tool because the social and economic benefits derived from such use provide incentives for people to conserve them" (IUCN 2000).

However, to better understand the legacies related to trophy hunting or hunting and wildlife conservation in Africa, the complex historical and political discourse upon which these legacies are rooted should be appreciated (Gibson 1999; Carruthers 2008; Duffy et al. 2016). Several authors use the political ecology perspective to understand environmental or conservation related challenges (Blaikie and Brookfield 1987; Bryant and Bailey 1997; Vaccaro et al. 2013). Broadly, political ecologists tend to agree that environmental challenges in developing countries are not just a reflection of policy or market failures, but are an indicator of broader political and economic forces which are often linked to the spread of capitalism (Bryant and Bailey 1997). Past political, economic and environmental injustices dating to the colonial period underpin some of the controversies unfolding in the conservation sector.

\section{Review findings and discussion}

Little is documented about the political ecology of conservation and trophy hunting in the pre-colonial period in Africa (Newsham 2002; Murombedzi 2003), hence, the main themes emerging from a review of literature focused on the colonial and post-colonial periods. Emerging subthemes included the motives for hunting and its different forms, who was involved, associated socio-political developments, legislative developments and reforms, and cultural diffusion and ethnocentric-based power dynamics. These subthemes help to articulate wildlife conservation and associated political history in the southern African context. 
Hunting and conservation in Africa: a historical perspective

The colonial and post-colonial periods had profound effects on the course of the hunting and conservation narrative (Gibson 1999). The effects and impacts associated with these periods were also linked to the politicization and commodification of conservation and natural resources driven by capitalist interests (Murombedzi 2003). The impacts of politicization and commodification of natural resources on the sociocultural, economic, ecological and ideological landscapes of Indigenous peoples and their relationship with biodiversity have been articulated by many authors (Ichikawa 1983; Murombedzi 2003; DeGeorges and Reilly 2009; Child 2013; Damm 2015). For example, in the colonial period, hunting shifted from a subsistence orientation to a sport dominated by foreign hunters as demand from the outside world increased (Gibson 1999). For instance, early game laws in southern Africa which were established around 1886 in the Cape of Good Hope, South Africa (Brown 2002) promoted international trade and commercial hunting for ivory and skins, in response to an increased demand from Europe and Asia. This opened the floodgates for excessive exploitation of African wildlife, which continues to fascinate residents of many developed countries (Gibson 1999). Over-exploitation of game also followed power politics, manipulation and deception (e.g. the Rudd Concession in the then Southern Rhodesia in October 1888) (Zvobgo 2009) and the use of advanced and powerful weapons by colonists, foreign hunters, explorers, commercial farmers and missionaries (Pilgram and Western 1986; Anderson and Grove 1987; Beinart 2000; Van der Merwe and du Plessis 2014).

In East Africa, Steinhart (1989: 247) states that "hunting during the colonial era was an element in the struggle for power among the various forces vying for control of Kenya's resources of land, water and animals, wild and domesticated." This statement resonates with what was unfolding elsewhere during the same period in most colonized countries, where hunting was part of a power struggle for control and expropriation of Africa's natural resources (Garland 2008). Theodore Roosevelt, who is credited with developing hunting ethics in the United States, promoted fighting and hunting "as means of acquiring the attributes of masculinity, without losing the refined status of whiteness" (Mayer 2002: 76). Hunting, apart from being commercialized, took on a political and exploitative character consistent with the racial politics of the day. The historical accounts of hunters like Frederick Selous, Captain C.H. Stand, Alfred ArkellHardwick, W.D.M. Bell and A.H. Neumann in hunting expeditions in Africa portray exploitative tendencies (Steinhart 1989). Frederick Selous was decorated as "... an old-time Victorian hero" (Cejas 2007: 124), because of his prowess in hunting big game across southern Africa. In one incident Selous boasts of killing many elephants, 28 in three hunting seasons (Selous 1970). Others like William Finaughty, Henry Hartley and Karl Mauch were much involved in massive elephant hunts in Africa (Grove 1987).

In the 19th century, colonialism acted as a conduit for radical environmental changes, some of which were meant to correct self-inflicted negative outcomes in the field of wildlife management, especially in what was formally referred to as the "British African Empire" (Neumann 2002: 24). Attempts were made to establish standardized wildlife conservation legislation after realizing the serious decline of various animal populations (Neumann 2002). Such changes in the then colonized parts of Africa were to a large extent influenced by developments in Europe and the USA where actions in response to threats to environmental sustainability and biodiversity loss were unfolding (Grove 1987). Jones (2006) concluded that the realization of species depletion in Europe caused major compromises for Africa's wildlife as the western colonial powers introduced a raft of measures meant to halt biodiversity loss and human-induced species extinctions. For example, some early interventions to protect species from extinction included the establishment of the Royal Society for the Protection of Birds (RSPB) in 1891 and the signing in 1900 of the 'Convention for the Preservation of Wild Animals, Birds and Fish in Africa' by European countries with colonies in sub-Saharan Africa (Jones 2006). However, authors like Anderson and Grove (1987) see these interventionist efforts differently as they argue that Europeans fully imposed their image of Africa (i.e. a special kind of Eden) upon the reality of the African landscape, arguing it was this kind of Eden they were trying to preserve. This construct is said to have resulted in the justification, at that time, of a developed Europe and wild Africa, which was envisaged to remain a wilderness for the enjoyment of the rich Western bourgeoisie (Adams and McShane 1996; Newsham 2002). 
In southern Africa, a raft of measures to address threats to wildlife included the introduction of a cocktail of conservation laws and approaches which had a dual impact; i.e. pro-conservation, but largely excluded the Indigenous peoples' aspirations and traditional practices. A case in point was the promulgation of legislative instruments such as the Game Law Amendment Act (1886) of the Cape of Good Hope, the Game Law Amendment Act (1891) and the Game Preservation Ordinance 'No. 6 of 1899' in Southern Rhodesia meant to regulate wildlife utilization through a licensing and permit system to reduce the growing export of game and the prevention of its commercialization (Child 1977; Masona 1987; Murombedzi 2003; Van der Merwe and du Plessis 2014). Nonetheless, the requirements of these laws were found hostile to the Indigenous peoples' traditions. Some of these Game Laws, introduced by the British South African Company (BSAC), banned people from selling hunted game without a license. The cost of each license varied depending on the class of the species from 1 pound for a bird species to 5 pounds for game animals (Mutwira 1989). The costs of these licenses were beyond the reach of many of the Indigenous black majority at that time, resulting in Indigenous hunters resorting to illegal hunting as they struggled to pursue their traditional lifestyles. So the introduction of such conservation laws reinforced the protectionist ideology resulting in the strict centralization of wildlife management (Child 1977; Murombedzi 2003).

Apart from the physical disarticulation, these laws and approaches had a spiritual and philosophical impact on Indigenous people by substituting their conservation philosophies and traditional ecological knowledge systems for western conservation knowledge deemed to be superior (Pimbert and Pretty 1997; Neumann 2002; Muboko and Murindagomo 2014). In African communities, traditional or Indigenous knowledge, values and practices accumulated and passed down generations as part of the conservation and cultural heritage discourse guided human societies in their interactions with the surrounding natural environment (Van Zanten 2004). The superiority discourse that accompanied colonialism prioritized western knowledge and philosophies, but initially with poor understanding of African wildlife and conservation (Beinart 1989; Alvares 2011; Smith 2013). In fact, authors like Agrawal (1995) state that earlier theorists viewed traditional African knowledge and traditions as anti-development. Woodburn (1997) in a study of local discrimination against hunter-gatherer minorities in sub-Saharan Africa, specifically in the central African rainforest region, described the marginalization suffered by forest people who were denied their hunting and land rights because they were seen as 'nomadic' and therefore primitive. Myers (1988) observes Eric Wolf's criticism of the anthropological treatments of non-westerners as 'peoples without a history.' These ethnocentric views were used to fortify the discrimination agenda against Indigenous peoples and their knowledge in every aspect, including reducing access to land and wildlife resources (Woodburn 1997). These ethnocentric views and associated discriminatory practices were also behind land expropriations which accompanied a racially structured system based on ideological, economic and political interests (Murphree 2005).

Theories of development were also to blame for discrimination against African knowledge systems. For instance, Hesse and Wissink (2004) blame two: modernization and dependency for sidelining indigenous knowledge. Modernization theory subscribes to the notion that development "can only occur if African societies abandon their traditional, social, institutional structures, attitudes as well as behavioral patterns" (Sodaro and Michael 2001:3512). Dependency theory, far less evident today, is premised on a debatable proposition that the South is dependent on the North, and therefore its knowledge is inconsequential to the development discourse. Communities practicing and using indigenous knowledge are frequently seen as primitive and outdated (Ocholla 2007). These and other prejudicial ideologies and theories were part of a cocktail of justifications for discriminatory conservation laws and practices.

The operationalization of such discriminatory ideologies and theories has had a double effect: the salvaging of some endangered and threatened species from the vortex of extinction (Attwell and Cotterill 2000), but simultaneously the marginalization of some groups. The latter has led to Indigenous peoples developing negative attitudes towards wild animals (Grove 1987; Pimbert and Pretty 1997; Dowie 2011). These have led to resistance against government-driven conservation programs, resulting in the further decline of wildlife populations (Jones 2006).

The challenges of dwindling wildlife populations despite strict legal protection, prompted the formulation of legal frameworks empowering governments to formally establish protected areas (PAs) in the 
early 1900s. Protected Areas were meant to intensify and fortify the protection of wildlife from factors threatening their survival. For example, in Zimbabwe, the enactment of the Game and Fish Preservation Act of 1929 empowered governors to form game reserves and establish the necessary management structures (Murombedzi 2003). This was followed by the 1949 National Parks Act, which saw the accelerated establishment of PAs across the country (Murombedzi 2003). It is against this background that many acknowledge that the establishment of some of the $20^{\text {th }}$ century PAs originated from the practice of hunting and overexploitation of wildlife (Jones 2006). Although PAs had inherent problems of exclusivity and exclusions, they were effective in protecting the wildlife heritage as evidenced by biodiversity trends (Carruthers 2008; Watson et al. 2016). However, the exclusion of local people from their land created acrimonious relations between the local communities and PA management (Colchester 2004). In the later colonial and early post-colonial times the need to address these problems became more urgent. Some of the efforts to address such problems were seen through further legislative changes and the initiation of benefitbased conservation approaches under the banner of community-based natural resources management (CBNRM) and similar programs.

Post-colonial legislative reforms and benefit-based approaches in southern Africa, the case of CAMPFIRE in Zimbabwe

In the post-colonial period in Africa (i.e. from the 1960-1990s) the importance of co-existence of PAs and adjacent local communities, and the recognition of the existence of wildlife outside designated PAs saw some governments embarking on a reformist agenda towards conservation legislation (McNeely 1995; Gibson 1999; Rodrigues et al. 2004; Johannesen and Skonhoft 2005; Larson et al. 2016). This resulted in the legislative transformations of the 1960s and 1970s that conferred various entitlements over wildlife, especially to landholders and later to rural communities living with wildlife outside designated PAs (Beinart 1989; Hackel 1999; Murombedzi 2003; Bond 2013; Muboko and Murindagomo 2014). This legislative shift was not only influenced by changing political views at the global and continental levels at the end of the 1960s, but also reflected a need for local community empowerment and an awakening of the power and influence of indigenous knowledge in conservation and environmental management (McGregor 2004; Adams and Hutton 2007; Mace 2014). Such shifts were expressed by many authors, e.g. David Suzuki, a public scientist and environmentalist, who said "My experience with Aboriginal people convinced me... of the power and relevance of their knowledge and world view in a time of imminent global ecocatastrophe" (1992: xliv).

Such legislative and attitudinal transformation culminated in a number of changes in Africa, for instance, in 1968 some African countries signed the African Convention on the Conservation of Nature and Natural Resources (revised 2003) which states that conservation must also pay attention to the resources local communities depend on (Van der Linde 2002; IUCN 2004). This convention reflects a build-up from changes to conservation practice dating to the 1960s, sweeping across southern Africa and beyond (Child and Child 2015). For instance, in Zimbabwe, the promulgation of the Wildlife Conservation Act of 1960 gave landholders incentives for conservation (Child 1996; Taylor 2009; Bond 2013). It responded to the need to curb the threats toward animal populations and marked a significant shift in wildlife policy from the previous preservationist approach to commercial utilization of wildlife. Also, the later amendments to the Zimbabwe Parks and Wildlife Act (Chapter 14) in 1975 and 1982, and the later Parks and Wildlife Act of 2001 (Chapter 20: 14) provided greater opportunities for landholders and local community participation in wildlife protection and sustainable utilization even outside the Parks Estate. These legislative reforms and the conservation movement saw the birth of many initiatives under the banner of CBNRM and similar such programs whose evolution in southern Africa is well documented (Child 1996, Hasler 1999, Logan and Moseley 2002, Child and Child 2015). These CBNRM programs in southern Africa are exemplified by the Administrative Management Design (ADMADE) for Game Management Areas in Zambia (Mwenya et al. 1988), Tchuma Tchato in Mozambique (Anstey 2000), the communal conservancy system in Namibia (Nott et al. 2004, Weaver and Petersen 2008) and the Community Areas Management Programme for Indigenous Resources (CAMPFIRE) in Zimbabwe (Murphree 2005). 
In Zimbabwe, CAMPFIRE, which succeeded the Wildlife Industries New Development For All (WINDFALL) project, was initiated in Mahenye and Chipinge 1982 after the Parks and Wildlife Act 14 of 1975 was amended in 1982 to confer user rights through the conferment of the appropriate authority (AA) status to respective landowners and rural district councils (RDCs) endowed with wildlife resources (Association 2003; Frost 2006). CAMPFIRE was based on the assumption that involving local communities in wildlife conservation and sharing the resultant benefits will promote long term sustainability of the wildlife heritage and improve rural development (Harrison 2015). Hence, it was also designed to decentralize financial benefits generated from using wildlife in order to create incentives for wildlife conservation by landowners and local communities (Hutton et al. 2005; Frost and Bond 2008; Murphree and Taylor 2009; Fabricius 2013). Central to its design were the following principles, outlined by Murphree (1992; 2005) and summarized below, that:

1. Effective management of wildlife is best achieved by giving it focused value for those who live with it.

2. Differential inputs must result in differential benefits.

3. There must be a positive correlation between quality of management and magnitude of benefit.

4. The unit of proprietorship should be the unit of production, management and benefit, and

5. The unit of proprietorship should be as small as practicable within ecological and sociopolitical constraints.

Critical to these intertwined principles was the quest for benefit realization for local communities and wildlife conservation. These benefits were both tangible and intangible. Intangible benefits included inculcating a sense of ownership of resources, tolerance, positive attitudes and perceptions of wildlife conservation and strengthening of local ecological knowledge. Tangible benefits included cash benefits, wage employment, provision of game meat, diversified livelihoods options, reduced human-wildlife conflicts (HWCs) and use of wildlife conservation as an alternative land use option. Between 1989 and 2006, 90\% of revenue was "earned from the lease of sport hunting rights to commercial safari operators" (Tchakatumba et al. 2019: 120) with the balance coming from lease of tourism rights, legitimate sale of ivory and hides, and other minor transactions.

To roll out the program and realize the benefits, government initially funded the CAMPFIRE program, but around the late 1980s until 2003 support from donors like the United States Agency for International Development (USAID), the Norwegian Agency for International Development and several local NGOs and development partners among others, gave impetus to the program (Frost 2006; Tchakatumba et al. 2019). During this period households received some cash dividends, resulting in positive changes of local communities' attitudes and perceptions towards wildlife conservation as wildlife resources were valorized, to the extent that wildlife conservation became a viable land use option (Child 1996; Taylor 2009). The disbursement of dividends was structured based on the CAMPFIRE revenue distribution model, revised in 2002, which stated that no less than $55 \%$ of gross revenue should go to the producer communities (usually at ward level), 4\% goes to the CAMPFIRE Association, 15\% goes to the responsible RDCs and 26\% is allocated for wildlife management (usually at the RDC level) (CAMPFIRE Association, 2003).

These revised revenue guidelines superseded the ones produced in 1991, which recommended that at least $50 \%$ of the revenue goes to the wildlife producer communities, up to $35 \%$ is invested in wildlife management, and up to $15 \%$ should go to the RDC as a levy for CAMPFIRE administrative purposes. One of the major weaknesses of the 1991 guidelines was that they were mere recommendations. The development of the revenue distribution guidelines was a step in attempting to satisfy principles like 'effective management of wildlife is best achieved by giving it focused value for those who live with it', and 'differential inputs must result in differential benefits.' The distribution of revenue to producer communities brought some relief and positive changes, for example, Murphree (1991) reported that in Kanyurira community (i.e. Masoka community) in Mbire District and in Chikwarakwara community in Beit-Bridge District, negative attitudes 
towards wildlife were transformed to positive ones following the introduction of CAMPFIRE around 1988. Also, through trophy hunting, opportunities were opened up to benefit a broad spectrum of people including local communities, especially those living close to PAs (Murombedzi 2003; Murphree 2005; Frost and Bond 2008; Tchakatumba et al. 2019). The CAMPFIRE program assisted rural development through developing infrastructure such as schools, clinics and bridges and also opened up employment opportunities to local people in various capacities including resource monitors, CAMPFIRE committee members, professional trackers, professional hunters, professional skinners and cooks. For instance, to date, over one million people are directly or indirectly employed in the hunting and photographic sector in Africa, though these jobs are threatened by emergent disease epidemics like the Covid-19 pandemic and trophy hunting bans.

After 2003 benefits such as household cash dividends began to shrink, amidst the fact that the amounts were progressively becoming smaller, and in some areas such a provision ceased in favor of community-based development projects (Frost 2006; Tchakatumba et al. 2019). The shrinkage or cessation of household cash dividends was due to a number of compounding factors such as reduced direct government support due to a constrained fiscal space, donor fatigue, limited revenue streams, increased numbers of beneficiaries, rising corruption levels in Zimbabwe and an inflationary macro-economic environment. The country entered a political stalemate traceable to its land reform program, invasions of private land, and hyperinflation. Private and public infrastructure collapsed, affecting wildlife management, and bilateral donor funds were withdrawn while the American and European clientele dwindled (Tchakatumba et al. 2019).

Nevertheless, despite the successes scored by CAMPFIRE, it has its fair share of critics. Some of the criticisms are of trophy hunting and benefit-sharing. The criticisms surrounding trophy hunting and trade in wildlife and their products, such as live animal sales and ivory, are complex and deep, ranging from historical, socio-political, economic to ecological narratives (Baker 1997; Loveridge et al. 2007; Angula et al. 2018; Coulson et al. 2018; Batavia et al. 2019). For instance, consumer countries such as the USA, China and Japan and animal rights organizations like the US Humane Society, the League Against Cruel Sports and the Ban African Trophy Hunting Campaign, highlight that hunting is immoral and responsible for the extinction of a number of wildlife species (Tellecky and Lin 1995; Stiles 2004). With regard to community benefits, a number of authors raise concerns over the lack of evidence for the claim that revenue from trophy hunting is reinvested in conservation and local community development (Baker 1997; Sullivan 2003; LeaderWilliams and Hutton 2005; Frost 2006). In Zimbabwe's CAMPFIRE areas, despite the revenue distribution model, trophy hunting revenue tends to accrue most to leased hunting operators, then Rural District councils, and lastly the local communities. The latter incur the greatest costs from living with wildlife. This violates the principle of 'differential inputs must result in differential benefits.' Lack of reinvestment into potential beneficiary communities is blamed on a lack of political will and weak governance with misplaced priorities, rampant corruption, the politicization of wildlife resources, and poorly managed community-based wildlife programs (Baker 1997; Cooney et al. 2017). The implementation of the revised CAMPFIRE policy finalized in 2018 (before the current Covid-19 pandemic) is expected to address these concerns.

Within the criticisms, it also appears that legislative changes and devolution were rather slow or inadequate to deliver behavioral and institutional reforms at the grassroots level. Change required more support and time, especially in terms of further devolution to the lowest level of rural community administrative structures. For example, CAMPFIRE's heavy reliance on trophy hunting (i.e. only wild animals of economic value out of the key four resources, i.e. water, wild animals, grass and forests; Taylor 2009) provided mainly short-term financial benefits, and tragedies in the long-term, especially in terms of program sustainability. Failure to price and allocate resources efficiently, political interference and having weak local community-based institutions and capacities have been cited as some of the weaknesses of CBNRM programs like CAMPFIRE (Blaikie 2006; Child 1996; Logan and Moseley 2002). There are also a number of arguments against trophy hunting including the concern that a thin line exists between poaching and legal hunting, and that commercial interests often override conservation obligations (Hall-Martin 1992; Frank 2018). Again, trophy hunting in southern Africa is reliant on foreign hunters, and the Covid-19 pandemic has severely restricted global mobility.

Those who support trophy hunting and trade have some compelling arguments. They argue that a ban on trophy hunting breaks the resilience of communities living with wild animals, removing the incentive to 
conserve them (Naidoo et al. 2016), especially in human-dominated landscapes (Western et al. 2015; Mbaiwa 2018). Some authors argue that wildlife conservation financing is normally beyond the capacity of governments and local communities (Crosmary et al. 2015) or is being monetized, on private land (Büscher 2021). Wildlife tourism is not enough to offset the costs associated with its conservation (Selier and Di Minin 2015), and evidence in Kenya (Nelson 2012) and Uganda (Makumbi and Manyindo 2000) suggests banning trophy hunting does not translate to successful species protection. The argument is that a ban on live wildlife trade and its products (by those who do not live with wildlife) doesn't address the need for sustainable conservation funding and wildlife management, or how to improve the livelihoods of communities living with wildlife.

Some countries with successful conservation programs, as evidenced through a booming wildlife population and diverse species, liken trade bans to an onslaught on their conservation successes. Banning trade in wildlife and its products is also viewed as not just an obsolete and ineffective method with little relevance in today's globalized economy, but also as a decision based on emotions and politics (Murombedzi 1996; Murphree 2005). Hence, criticisms over trophy hunting and advocating for wildlife trade bans have the potential to threaten both livelihoods of trophy hunting-dependent communities and sustainable wildlife conservation efforts in the long-term.

\section{Conclusions and recommendations}

The main conclusion from this review is that socio-political and legislative changes have had significant impacts on wildlife conservation, trophy hunting and associated benefits in southern Africa during and after colonization. Power and politics influenced how colonial protectionist wildlife conservation philosophies were implemented, and this had differential effects on groups of people along racial, social and economic lines. The political ecology of wildlife conservation and trophy hunting has evolved since the colonial period. Although benefit-based approaches established after the colonial era marked a significant departure from colonial conservation practices, policies and philosophies, they are often criticized for their inability to achieve some of their intended principles or objectives. Most of them lack strong institutional frameworks, law enforcement, real community participation, or fair access and benefit sharing mechanisms. There is a mismatch between the needs and interests of different actors, and these inadequacies headline the current conservation debate (Courchamp et al. 2006).

A first recommendation is that controlled and sustainable trophy hunting and wildlife trade should be considered, although this should be circumstantial and place-based. Recognizing that there is not a 'one-size fits all' strategy in conservation, in the case of sustainable, controlled trophy hunting and wildlife trade, guiding instruments or practices need to be respected, such as those outlined by the IUCN SSC's five components (i.e. Biological Sustainability; Net Conservation Benefit; Socio-Economic-Cultural Benefit; Adaptive Management and Accountable and Effective Governance) (IUCN 2012).

Secondly, the inherent weaknesses in the trophy hunting and wildlife trade business and benefit-based approaches should not preclude their positive contribution to conservation, community participation and livelihoods. Hence, priority should be given to capacity building and strengthening the institutions and systems that manage wildlife protection, management, benefit and cost sharing and trade. Authors like Makumbi and Manyindo (2000), recommend a model that considers benefit and costs in conservation decision-making. Lessons can be drawn from what can be termed a 'conservation democracy concept or system', which is located in the resource governance domain. The involvement of directly-affected people and their interests in conservation decision-making processes is essential for the achievement of a conservation goal. In addition, conservation financing models and practices, education and legislative frameworks need continuous development. Alternatives to trophy hunting must be found, where it is unviable (Spenceley 2006; Clements et al. 2016). 


\section{References}

Adams, J.S. and T.O. McShane. 1996. The myth of wild Africa: conservation without illusion. Berkeley: University of California Press.

Adams, W.M. and J. Hutton. 2007. People, parks and poverty: political ecology and biodiversity conservation. Conservation and Society 5(2): 147-183.

Agrawal, A. 1995. Indigenous and scientific knowledge: some critical comments. Indigenous Knowledge and Development Monitor 3(3): 3-6. reprint

Aiyadurai, A. 2011. Wildlife hunting and conservation in Northeast India: a need for an interdisciplinary understanding. International Journal of Galliformes Conservation 2: 61-73.

Akama, J.S. 2007. Controversies surrounding the ban on wildlife hunting in Kenya: an historical perspective. In Lovelock, B. (ed.). Tourism and the consumption of wildlife. London: Routledge. Pp. 95-108.

Alpert, P. 1996. Integrated conservation and development projects. BioScience 46(11): 845-855.

Alvares, C. 2011. A critique of Eurocentric social science and the question of alternatives. Economic and Political Weekly 46(22): 72-81.

Anderson, D. and R.H. Grove. 1987. The scramble for Eden: past, present and future in African conservation. In D. Anderson and R.H. Grove (eds.). Conservation in Africa: people, policies and practice. Cambridge: Cambridge University Press. Pp. 1-12.

Anderson D. and R.H. Grove (eds.). 1987. Conservation in Africa: people, policies and practice. Cambridge: Cambridge University Press.

Angula, H.N., G. Stuart-Hill, D. Ward, G. Matongo, R.W. Diggle and R. Naidoo. 2018. Local perceptions of trophy hunting on communal lands in Namibia. Biological Conservation 218: 26-31.

Anstey, S. 2000. History matters: institutional change and CBNRM in Sanga District, northern Mozambique. Constituting the Commons: Crafting Sustainable Commons in the New Millennium, the Eighth Conference of the International Association for the Study of Common Property, Bloomington, Indiana, USA, May.

Association. 2003. Revised CAMPFIRE revenue distribution guidelines. Zimbabwe: CAMPFIRE Association.

Attwell, C. and F. Cotterill. 2000. Postmodernism and African conservation science. Biodiversity and Conservation 9(5): 559-577.

Baker, J.E. 1997. Trophy hunting as a sustainable use of wildlife resources in southern and eastern Africa. Journal of Sustainable Tourism 5(4): 306-321.

Batavia, C., M.P. Nelson, C.T. Darimont, P.C. Paquet, W.J. Ripple and A.D. Wallach. 2019. The elephant (head) in the room: a critical look at trophy hunting. Conservation Letters 12(1): e12565.

Beinart, W. 1989. Introduction: the politics of colonial conservation. Journal of Southern African Studies 15(2): 143-162.

Beinart, W. 2000. African history and environmental history. African Affairs 99(395): 269-302.

Bird, D.W., R.B. Bird and C.H. Parker. 2005. Aboriginal burning regimes and hunting strategies in Australia's Western Desert. Human Ecology 33(4): 443-464.

Blaikie, P.M. 2006. Is small really beautiful? Community-based natural resource management in Malawi and Botswana. World Development 34(11): 1942-1957.

Blaikie, P.M. and H.C. Brookfield. 1987. Land degradation and society. London: Methuen.

Bond, I. with B. Child, D. de la Harpe, B. Jones, J. Barnes and H. Anderson. 2013. Private land contribution to conservation in South Africa. In B. Child (ed.). Parks in transition: biodiversity, rural development and the bottom line. London: Routledge. Pp. 46-79.

Brandon, K., K.H. Redford and S. Sanderson. 1998. Parks in peril: people, politics, and protected areas. Washington DC: Island Press. 
Brockington, D. and J. Igoe. 2006. Eviction for conservation: a global overview. Conservation and Society 4(3): 424-470.

Brown, K. 2002. Cultural constructions of the wild: the rhetoric and practice of wildlife conservation in the Cape Colony at the turn of the twentieth century. South African Historical Journal 47(1): 75-95.

Bryant, R.L. and S. Bailey. 1997. Third world political ecology. London: Routledge.

Buckley, R. and A. Mossaz. 2015. Hunting tourism and animal conservation. Animal Conservation 18(2): 133-135.

Büscher B. 2021. Between overstocking and extinction: conservation and the intensification of uneven wildlife geographies in Africa. Journal of Political Ecology 28.

Carruthers, J. 2008. Conservation and wildlife management in South African National Parks 1930s-1960s. Journal of the History of Biology 41(2): 203-236.

Cejas, M. 2007. Tourism "Back in Time": performing "the Essence of Safari" in Africa. Intercultural Communication Studies 16(3): 121-134.

Child, B. 1996. The practice and principles of community-based wildlife management in Zimbabwe: the CAMPFIRE programme. Biodiversity and Conservation 5(3): 369-398.

Child, G. 1995. Managing wildlife successfully in Zimbabwe. Oryx 29(3): 171-177.

Child, G. 1996. The role of community-based wild resource management in Zimbabwe. Biodiversity and Conservation 5(3): 355-367.

Child, G. 2013. Growth of modern nature conservation in Southern Africa. In B. Child (ed.). Parks in transition: biodiversity, rural development and the bottom line. London: Routledge. Pp. 24-45.

Child, G. and B. Child. 2015. The conservation movement in Zimbabwe: an early experiment in devolved community based regulation. African Journal of Wildlife Research 45(1): 1-17.

Child, G.F.T. 1977. Problems and progress in nature conservation in Rhodesia. Koedoe 20(2): 116-137.

Clements, H.S., J. Baum and G.S. Cumming. 2016. Money and motives: an organizational ecology perspective on private land conservation. Biological Conservation 197: 108-115.

Cohen, G. 1990. Memory. Milton Keynes: Lawrence Erlbaum.

Colchester, M. 2004. Conservation policy and indigenous peoples. Environmental Science and Policy 7(3): 145-153.

Coulson, T., S. Schindler, L. Traill and B.E. Kendall. 2018. Predicting the evolutionary consequences of trophy hunting on a quantitative trait. The Journal of Wildlife Management 82(1): 46-56.

Courchamp, F., E. Angulo, P. Rivalan, R.J. Hall, L. Signoret, L. Bull and Y. Meinard. 2006. Rarity value and species extinction: the anthropogenic Allee effect. PLoS Biology 4(12): e415.

Crosmary, W.G., S. Côté and H. Fritz. 2015. The assessment of the role of trophy hunting in wildlife conservation. Animal Conservation 18(2): 136-137.

Damm, G.H. 2005. Hunting in South Africa: facts, risks and opportunities. African Indaba e-newsletter 3(4): $1-23$.

Damm, G.H. 2015. Branding hunting. African Indaba e-Newsletter 13(6): 1-3.

DeGeorges, P.A. and B.K. Reilly. 2009. The realities of community based natural resource management and biodiversity conservation in Sub-Saharan Africa. Sustainability 1(3): 734-788.

Di Minin, E., N. Leader-Williams and C.J. Bradshaw. 2016. Banning trophy hunting will exacerbate biodiversity loss. Trends in Ecology and Evolution 31(2): 99-102.

Dickson, B., J. Hutton and W.M. Adams (eds.). 2009. Recreational hunting, conservation and rural livelihoods: science and practice. Chichester: Wiley.

Dowie, M. 2011. Conservation refugees: the hundred-year conflict between global conservation and native peoples. Cambridge MA: MIT Press.

Duffy, R., F.A. St John, B. Büscher and D. Brockington. 2016. Toward a new understanding of the links between poverty and illegal wildlife hunting. Conservation Biology 30(1): 14-22. 
Fabricius, C. 2013. The fundamentals of community-based natural resource management. In C. Fabricius, E. Koch, S. Turner and H. Magobe (eds.). Rights resources and rural development: Community-based Natural Resource Management in Southern Africa. London: Routledge. Pp. 18-58.

Festa-Bianchet, M. 2017. When does selective hunting select, how can we tell, and what should we do about it? Mammal Review 47(1): 76-81.

Fitzwater, W.D. 1970. Trapping-the oldest profession. Proceedings of the 4th Vertebrate Pest Conference.

Frank, H. 2018. Why is poaching still happening? The Sentry. Sept. 19.

Frost, G.H., and I. Bond. 2006. CAMPFIRE and payments for environmental services. London: International Institute for Environment and Development.

Frost, P.G. and I. Bond. 2008. The CAMPFIRE programme in Zimbabwe: payments for wildlife services. Ecological Economics 65(4): 776-787.

Garland, E. 2008. The elephant in the room: confronting the colonial character of wildlife conservation in Africa. African Studies Review 51(3): 51-74.

Gibson, C.C. 1999. Politicians and poachers: the political economy of wildlife policy in Africa. Cambridge: Cambridge University Press.

Godoy, E.S. 2020. Sympathy for Cecil: gender, trophy hunting, and the western environmental imaginary. Journal of Political Ecology 27: 759-774.

Grove, R. 1987. Early themes in African conservation: the Cape in the nineteenth century. In D. Anderson and R.H. Grove (eds.). Conservation in Africa: people, policies and practice. Cambridge: Cambridge University Press. Pp. 21-39.

Gunn, A.S. 2001. Environmental ethics and trophy hunting. Ethics and the Environment 6(1): 68-95.

Hackel, J.D. 1999. Community conservation and the future of Africa's wildlife. Conservation Biology 13(4): 726-734.

Hall-Martin, A.J. 1992. Distribution and status of the African elephant (Loxodonta africana) in South Africa, 1652-1992. Koedoe 35(1): 65-88.

Harrison, E.P. 2015. Impacts of natural resource management programmes on rural livelihoods in Zimbabwe-the ongoing legacies of CAMPFIRE. PSA Conference, Arcata, CA.

Hasler, R. 1999. An overview of the social, ecological and economic achievements and challenges of Zimbabwe's CAMPFIRE Programme. London: IIED.

Hesse, S. and H. Wissink. 2004. Incorporating Indigenous Knowledge Systems into the field of development. Cape Town: Juta.

Holt, S.J. and L.M. Talbot. 1978. New principles for the conservation of wild living resources. Wildlife Monographs 59: 3-33.

Hutton, J., W.M. Adams and J.C. Murombedzi. 2005. Back to the barriers? Changing narratives in biodiversity conservation. Forum for Development Studies 32(2): 341-370.

Ichikawa, M. 1983. An examination of the hunting-dependent life of the Mbuti Pygmies, Eastern Zaire. African Studies Monographs 4: 55-76.

IUCN. 2000. The IUCN Policy Statement on Sustainable Use of Wild Living Resources. Gland: IUCN.

IUCN. 2004. An introduction to the African Convention on the Conservation of Nature and Natural Resources. Gland: IUCN.

IUCN. 2012. IUCN SSC Guiding principles on trophy hunting as a tool for creating conservation incentives. Ver 1: 1-11. Gland: IUCN.

Johannesen, A.B. and A. Skonhoft. 2005. Tourism, poaching and wildlife conservation: what can integrated conservation and development projects accomplish? Resource and Energy Economics 27(3): 208-226.

Jones, S. 2006. A political ecology of wildlife conservation in Africa. Review of African Political Economy 33(109): 483-495. 
Kamal, S., M. Grodzińska-Jurczak and G. Brown. 2015. Conservation on private land: a review of global strategies with a proposed classification system. Journal of Environmental Planning and Management 58(4): 576-597.

Kideghesho, J.R. 2006. Wildlife conservation and local land use conflicts in Western Serengeti Corridor, Tanzania. PhD dissertation. Trondheim: Norwegian University of Science and Technology.

Larson, L.R., A.L. Conway, S.M. Hernandez and J.P. Carroll. 2016. Human-wildlife conflict, conservation attitudes, and a potential role for citizen science in Sierra Leone, Africa. Conservation and Society 14(3): 205.

Leader-Williams, N., J. Harrison and M.J.B. Green. 1990. Designing protected areas to conserve natural resources. Science Progress 74(2): 189-204.

Leader-Williams, N. and J. Hutton. 2005. Does extractive use provide opportunities to offset conflicts between people and wildlife? In R. Woodroffe, S. Thirgood and A. Rabinowitz (eds.). People and wildlife, conflict or co-existence? Cambridge: Cambridge University Press. Pp. 140-161.

Leopold, A. 1987(1933). Game management. Madison: University of Wisconsin Press.

Lindsey, P., P. Roulet and S. Romanach. 2007. Economic and conservation significance of the trophy hunting industry in sub-Saharan Africa. Biological Conservation 134(4): 455-469.

Lindsey, P.A. 2008. Trophy hunting in Sub Saharan Africa, economic scale and conservation significance. In Best practices in sustainable hunting: a guide to best practices from around the world. CIC Technical Series Publication No.1. Rome: International Council for Game and Wildlife Conservation/FAO. Pp. 41-47.

Lindsey, P.A., L. Frank, R. Alexander, A. Mathieson and S. Romanach. 2007. Trophy hunting and conservation in Africa: problems and one potential solution. Conservation Biology 21(3): 880-883.

Logan, B.I. and W.G. Moseley. 2002. The political ecology of poverty alleviation in Zimbabwe's Communal Areas Management Programme for Indigenous Resources (CAMPFIRE). Geoforum 33(1): 1-14.

Loveridge, A.J, A. Searle, F. Murindagomo and D. Macdonald. 2007. The impact of sport-hunting on the population dynamics of an African lion population in a protected area. Biological Conservation 134(4): 548-558.

Loveridge, A.J., J.C. Reynolds and E. Milner-Gulland. 2007. Does sport hunting benefit conservation? In D.W. McDonald and K. Service (eds.). Key topics in Conservation Biology. Oxford: Blackwell. Pp. 224-240.

Mace, G.M. 2014. Whose conservation? Science 345(6204): 1558-1560.

Makumbi, I. and J. Manyindo. 2000. Wildlife trade and the implementation on CITES in Uganda. Harare: Uganda Wildlife Society.

Martin, E. and D. Stiles. 2008. The ivory markets in the USA. London: Care for the Wild International.

Masona, T. 1987. Colonial game policy: a study of the origin and administration of game policy in southern Rhodesia-1890-1945. MA Dissertation. Harare: University of Zimbabwe.

Mayer, R. 2002. Artificial Africas: colonial images in the times of globalization. Hanover: University Press of New England.

Mbaiwa, J.E. 2018. Effects of the safari hunting tourism ban on rural livelihoods and wildlife conservation in Northern Botswana. South African Geographical Journal 100(1): 41-61.

McGregor, D. 2004. Coming full circle: Indigenous knowledge, environment, and our future. American Indian Quarterly 28(3/4): 385-410.

McNeely, J.A. 1995. Expanding partnerships in conservation. Washington DC: Island Press.

Miller, B., W. Conway, R.P. Reading, C. Wemmer, D. Wildt, D. Kleiman, S. Monfort, A. Rabinowitz, B. Armstrong and M. Hutchins. 2004. Evaluating the conservation mission of zoos, aquariums, botanical gardens, and natural history museums. Conservation Biology 18(1): 86-93.

Muboko, N. 2017. The role of transfrontier conservation areas and their institutional framework in natural resource-based conflict management: a review. Journal of Sustainable Forestry 36(6): 583-603. 
Muboko, N. and F. Murindagomo. 2014. Wildlife control, access and utilisation: lessons from legislation, policy evolution and implementation in Zimbabwe. Journal for Nature Conservation 22(3): 206-211.

Murombedzi, J.C. 2003. Pre-colonial and colonial conservation practices in southern Africa and their legacy today. Washington, DC: World Conservation Union (IUCN).

Murombedzi, J.C. 1996. Paying the Buffalo Bill: the impact and implications of external aid on the Communal Areas Management Programme for Indigenous Resources (CAMPFIRE). Harare: Cass NRM Working Paper No. 93/97.

Murphree, M.W. 2005. Congruent objectives, competing interests, and strategic compromise: concept and process in the evolution of Zimbabwe's CAMPFIRE, 1984-1996. Community conservation research in Africa: principles and comparative practice Working Papers 2. Manchester: IDPM.

Murphree, M. and R. Taylor. 2009. CBNRM in Africa: current constraints and opportunities. In Roe, D., F. Nelson and R. Sandbrook (eds.). Community management of natural resources in Africa: impacts, experiences and future directions. London: IIED. Pp. 105-120.

Mutwira, R. 1989. Southern Rhodesian wildlife policy (1890-1953): a question of condoning game slaughter? Journal of Southern African Studies 15(2): 250-262.

Mwenya, A., G. Kaweche and D. Lewis. 1988. Administrative management design for game management areas (ADMADE). Chilanga, Zambia: National Parks and Wildlife Service.

Myers, F.R. 1988. Critical trends in the study of hunter-gatherers. Annual Review of Anthropology 17(1): 261-282.

Naidoo, R., L.C. Weaver, R.W. Diggle, G. Matongo, G. Stuart-Hill and C. Thouless. 2016. Complementary benefits of tourism and hunting to communal conservancies in Namibia. Conservation Biology 30(3): 628-638.

Nelson, F. 2012. An analysis of international law, national legislation, judgements, and institutions as they interrelate with territories and areas conserved by indigenous peoples and local communities. Natural Justice Report 19. Bangalore.

Neumann, R.P. 1992. Political ecology of wildlife conservation in the Mt. Meru area of Northeast Tanzania. Land Degradation and Development 3(2): 85-98.

Neumann, R.P. 2002. The postwar conservation boom in British colonial Africa. Environmental History 7(1): 22-47.

Newsham, A. 2002. Participation: process, problematics and CAMPFIRE. Occasional Papers 89. Edinburgh University, Centre of African Studies.

Nott, C., A. Davis and B. Roman. 2004. The Torra Conservancy in Namibia. In C. Fabricius, E. Koch, S. Turner and H. Magome (eds.). Rights resources and rural development: Community-based Natural Resource Management in Southern Africa. London: Routledge. Pp. 200-209.

Nygren, A. 2004. Contested lands and incompatible images: the political ecology of struggles over resources in Nicaragua's Indio-Maíz Reserve. Society and Natural Resources 17(3): 189-205.

Ocholla, D. 2007. Marginalized knowledge: an agenda for indigenous knowledge development and integration with other forms of knowledge. International Review of Information Ethics 7(9): 1-10.

PHASA. 2006. General hunting information. Centurion, South Africa: PHASA.

Pilgram, T. and D. Western. 1986. Inferring hunting patterns on African elephants from tusks in the international ivory trade. Journal of Applied Ecology 23: 503-514.

Pimbert, M.P. and J.N. Pretty. 1997. Parks, people and professionals: putting 'participation' into protected area management. In K.B. Ghimire and M.P. Pimbert (eds.). Social change and conservation. London: Routledge. Pp. 297-330.

Principles. 2004. Addis Ababa guidelines for the sustainable use of biodiversity (CBD Guidelines). Montreal: Secretariat of the Convention on Biological Diversity.

Riddle, H.S., B.A. Schulte, A.A. Desai and L. van der Meer. 2010. Elephants - a conservation overview. Journal of Threatened Taxa 2(1): 653-651. 
Robinson, J. and E.L. Bennett. 2000. Hunting for sustainability in tropical forests. New York: Columbia University Press.

Rodrigues, A.S., H.R. Akcakaya, S.J. Andelman, M.I. Bakarr, L. Boitani, T.M. Brooks, J.S. Chanson, L.D. Fishpool, G.A. Da Fonseca and K.J. Gaston. 2004. Global gap analysis: priority regions for expanding the global protected-area network. BioScience 54(12): 1092-1100.

Sayer, J., T. Sunderland, J. Ghazoul, J.L. Pfund, D. Sheil, E. Meijaard, M. Venter, A.K. Boedhihartono, M. Day and C. Garcia. 2013. Ten principles for a landscape approach to reconciling agriculture, conservation, and other competing land uses. Proceedings of the National Academy of Sciences 110(21): 8349-8356.

Sayer, J.A., C. Margules, A.K. Boedhihartono, T. Sunderland, J.D. Langston, J. Reed, R. Riggs, L.E. Buck, B.M. Campbell and K. Kusters. 2017. Measuring the effectiveness of landscape approaches to conservation and development. Sustainability Science 12(3): 465-476.

Selier, S. and E. Di Minin. 2015. Monitoring required for effective sustainable use of wildlife. Animal Conservation 18(2): 131-132.

Selous, F.C. 1970. A hunter's wanderings in Africa. Lulu.com.

Sharp, R. and K.U. Wollscheid. 2009. An overview of recreational hunting in North America, Europe and Australia. In B. Dickson, J. Hutton and W.M. Adams (eds.). Recreational hunting, conservation and rural livelihoods: science and practice. London: Wiley. Pp. 25-38.

Smith, L.T. 2013. Decolonizing methodologies: research and Indigenous peoples. London: Zed.

Sodaro, M.J. 2001. Comparative politics: a global introduction. New York: McGraw-Hill.

Spenceley, A. 2006. Tourism in the Great Limpopo Transfrontier Park. Development Southern Africa 23(5): 649-667.

Steinhart, E.I. 1989. Hunters, poachers and gamekeepers: towards a social history of hunting in colonial Kenya. The Journal of African History 30(2): 247-264.

Stiles, D. 2004. The ivory trade and elephant conservation. Environmental Conservation 31(4): 309-321.

Sullivan, S. 2003. Protest, conflict and litigation: dissent or libel in resistance to a conservancy in north-west Namibia. In Berglund, E. and D. Anderson (eds.). Ethnographies of conservation: environmentalism and the distribution of privilege. Oxford: Berghahn Press.

Suzuki, D. 1992. A personal foreword: the value of native ecologies. In D. Suzuki and P. Knudtson. Wisdom of the elders: sacred native stories of nature. New York: Bantam Books. Xxvii.

Taylor, R. 1993. Wildlife management and utilization in a Zimbabwean communal land: a preliminary evaluation in Nyaminyami District, Kariba. Paper 32. WWF Multispecies Project.

Taylor, R. 2009. Community based natural resource management in Zimbabwe: the experience of CAMPFIRE. Biodiversity and Conservation 18(10): 2563-2583.

Tchakatumba, P.K., E. Gandiwa, E. Mwakiwa, B. Clegg and S. Nyasha. 2019. Does the CAMPFIRE programme ensure economic benefits from wildlife to households in Zimbabwe? Ecosystems and People 15(1): 119-135.

Tellecky, T. and D. Lin. 1995. Trophy of death. Humane Society of the United States News. 27-31.

Thomas, D.R. 2006. A general inductive approach for analyzing qualitative evaluation data. American Journal of Evaluation 27(2): 237-246.

Usher, M.B. 1986. Wildlife conservation evaluation: attributes, criteria and values. In Usher M.B. (ed.). Wildlife conservation evaluation. Dordrecht: Springer. Pp. 3-44.

Vaccaro, I., O. Beltran and P.A. Paquet. 2013. Political ecology and conservation policies: some theoretical genealogies. Journal of Political Ecology 20: 255-272.

Van der Linde, M. 2002. A review of the African Convention on Nature and Natural Resources. Africa Human Rights Law Journal 2: 33-59. 
Van der Merwe, P. 2018. Counting the contribution of hunting to South Africa's economy. The Conversation https://theconversation.com/counting-the-contribution-of-hunting-to-south-africas-economy-106715. Accessed 17 October 2019.

Van der Merwe, P. and L. du Plessis. 2014. Game farm and hunting tourism. Stellenbosch: African Sun Media.

Van Zanten, W. 2004. Constructing new terminology for intangible cultural heritage. Museum International 56(1-2): 36-44.

Watson, J.E., E.S. Darling, O. Venter, M. Maron, J. Walston, H.P. Possingham, N. Dudley, M. Hockings, M. Barnes and T.M. Brooks. 2016. Bolder science needed now for protected areas. Conservation Biology, 30(2): 243-248.

Weaver, L.C. and T. Petersen. 2008. Namibia communal area conservancies. Best Practices in Sustainable Hunting 1: 48-52.

Western, D., J. Waithaka and J. Kamanga. 2015. Finding space for wildlife beyond national parks and reducing conflict through community-based conservation: the Kenya experience. Parks 21(1): 51-62.

Westwood, P. 2001. Reading and learning difficulties: approaches to teaching and assessment. Camberwell, VIC: Australian Council for Educational Research.

Woodburn, J. 1997. Indigenous discrimination: the ideological basis for local discrimination against huntergatherer minorities in sub-Saharan Africa. Ethnic and Racial Studies 20(2): 345-361.

Zvobgo, C.J. 2009. A history of Zimbabwe, 1890-2000 and postscript, Zimbabwe, 2001-2008. Newcastle: Cambridge Scholars Publishing. 